\title{
ANALYSIS OF PACKAGING PRINT QUALITY WITH CTF AND CTCP PLATE MAKING SYSTEMS USING DUPLEX PAPER MATERIALS
}

\section{ANALISIS KUALITAS CETAK KEMASAN DENGAN SISTEM PEMBUATAN PELAT CTF DAN CTCP MENGGUNAKAN MATERIAL KERTAS DUPLEX}

\author{
Roni Fransiscus Lumbantoruan ${ }^{\mathrm{a}}$, Septia Ardiani ${ }^{{ }^{*}}$, Untung Basuki ${ }^{\mathrm{a}}$ \\ aTeknik Grafika, Politeknik Negeri Media Kreatif, Indonesia \\ *Email: septiaardiani@polimedia.ac.id
}

\begin{abstract}
Comparative analysis of packaging print quality was carried out on the printed output with reference to using Computer to Film $(\mathrm{CtF})$ and Computer to Conventional Plate $(\mathrm{CtCP})$. The comparison of the print results from the two systems is analyzed from cost, durability, and dot gain. In this analysis, 400 gram duplex paper was used and two types of print references were used, namely $\mathrm{CtF}$ and $\mathrm{CtCP}$. The pre-printing equipment used is the manufacture of conventional printing plates and plates. What is achieved when observing is comparing two print references with the help of a quality control (QC) tool. Before comparing the two print references, direct printing is done with the two print references, using an offset machine. The differences that exist in $\mathrm{CtF}$ and $\mathrm{CtCP}$ are caused by different irradiation processes. $\mathrm{CtF}$ goes through two irradiation processes while $\mathrm{CtCP}$ is in the irradiation process using only lasers. The irradiation process using a laser is uneven and makes the plate not get a raster (neat) result. This process is very influential with the result of the trigger. $\mathrm{CtF}$ goes through an iterative process but the results appear better than CtCP.
\end{abstract}

Keywords—Print packaging, Duplex, CtF, CtCp

\begin{abstract}
Abstrak-Analisis perbandingan kualitas cetak kemasan dilakukan pada hasil cetak dengan acuan menggunakan Computer to Film $(\mathrm{CtF})$ dan Computer to Conventional Plate (CtCP). Perbandingan hasil cetak dari kedua sistem ini dianalisis dari cost, ketahanan, dan dot gain. Pada analisis ini, digunakan material kertas duplex 400 gram dan menggunakan dua jenis acuan cetak yaitu $\mathrm{CtF}$ dan $\mathrm{CtCP}$. Peralatan pra cetak yang digunakan adalah plate making dan pelat cetak conventional. Hal yang dicapai ketika observasi adalah membandingkan dua acuan cetak dengan dibantu alat quality control (QC). Sebelum membandingkan kedua acuan cetak,
\end{abstract}


dilakukan pencetakan langsung dengan dua acuan cetak tersebut, menggunakan mesin ofset. Perbedaan yang terdapat pada $\mathrm{CtF}$ dan $\mathrm{CtCP}$ disebabkan oleh proses penyinaran yang berbeda. $\mathrm{CtF}$ melalui dua kali proses penyinaran sedangkan $\mathrm{CtCP}$ dalam proses penyinaran hanya menggunakan laser. Proses penyinaran menggunakan laser tidak merata dan membuat pelat tidak mendapatkan hasil raster yang matang (rapi). Proses ini sangat berpengaruh dengan hasil pelat. CtF melewati proses yang berulang ulang tetapi hasil yang muncul lebih baik dari CtCP. Kata Kunci-Cetak kemasan, Duplex, CtF, CtCp

\section{PENDAHULUAN}

Perkembangan ilmu pengetahuan dan teknologi yang terjadi sekarang ini menuntut industri untuk melakukan inovasi dalam memproduksi produknya demi meningkatkan kualitas. Produk yang berkualitas mempengaruhi jumlah konsumen. Konsumen saat ini tidak hanya menuntut kualitas produk yang unggul saja, tetapi juga menginginkan produk yang sesuai dengan keinginan mereka dengan waktu produksi yang lebih cepat, kualitas terbaik dan harga yang murah. Salah satu industri yang kini berkembang pesat adalah industri grafika. Grafika adalah suatu teknik atau cara penyampaian pesan, gagasan, informasi, pikiran, kesan perasaan memulai penggandaan dengan cara dicetak dan disajikan kepada khalayak (Wasono, 2008). Secara tidak langsung, industri grafika merupakan industri yang berkecimpung dalam media informasi (percetakan). Adapun bidang kerja grafika dibagi menjadi tiga bagian yaitu prepress (persiapan),press (cetak), dan postpress (penyelesaian).

Proses cetak-mencetak bertujuan untuk memperbanyak model dengan menggunakan suatu teknik dan alat dalam memprosesnya. Salah satu teknik cetak adalah cetak ofset. Teknik cetak datar atau biasa disebut ofset adalah teknik cetak yang menggunakan acuan datar dimana bagian yang mencetak kedudukannya sama datar dengan bagian yang tidak mencetak (image area dan non image area sama tingginya) (Nursidhi, 2018). Bagian image area pada pelat cetak ofset bersifat oleophylic menolak air dan menerima tinta. Sebaliknya bagian non image area bersifat hidrophylic menerima air dan akan menolak tinta (Sudiyamto dan Sutiyo, 2011). Acauan cetak sering disebut dengan pelat cetak. Pelat cetak memiliki peranan penting untuk hasil akhir cetakan. Semakin baik pelat cetaknya maka semakin baik juga hasil dari cetakan tersebut. Dengan semakin pesatnya teknologi 
di era zaman 4.0 mendorong hampir seluruh perusahaan percetakan di dunia menggunakan teknologi digital. Teknologi ini tentunya mempermudah alur pekerjaan pada proses cetak mencetak (pelat cetak). Teknologi ini ada pada bagian prepress atau dikenal dengan digital prepress, yang berarti prepress yang dioperasikan secara digital atau menggunakan komputer. Salah satu bagian dari digital preprees yaitu Computer to Film (CtF) maupun Computer to Conventional Plate (CtCP). Proses pembuatan plat cetak menggunakan teknologi $\mathrm{CtF}$ maupun $\mathrm{CtCP}$, tentunya memiliki keunggulan tersendiri maka dari itu perlu dianalisis kualitas cetak kemasan dari kedua teknologi ini. Analisis dilakukan pada material kertas duplex karena belum ada observasi tentang hal ini sebelumnya.

\section{METODE PENELITIAN}

Pada analisis kualitas cetak kemasan dengan sistem pembuatan pelat $\mathrm{CtF}$ dan $\mathrm{CtCP}$ material kertas duplex ini menggunakan dua jenis acuan cetak. Teknologi yang digunakan dalam membuat acuan cetak adalah:

\section{1) Computer to Film (CtF)}

\section{2) Computer to Conventional Plate (CtCP)}

Sedangkan dalam menentukan pilihan dari kedua acuan cetak tersebut diberikan kebebasan kepada customer dan tentunya pasti hasil dari kedua acuan tersebut saat mencetak akan berbeda.

Peralatan pra cetak yang digunakan adalah plate making dan pelat cetak conventional. Perusahaan melakukan kerjasama kepada CV lain yang bergerak khusus dalam pembuatan pelat cetak $\mathrm{CtCP}$ dan juga pembuat film. Jika film yang digunakan konsumen sesuai dengan perusahaan maka dilakukan kegiatan manual pra cetak yaitu montase dan proses penyinaran image pada film ke pelat menggunakan plate making. Kebijakan ini sangat memperkecil resiko terhadap kesalahan yang dilakukan dalam memenuhi keinginan konsumen. Kesalahan yang terjadi pun masih terus ada mulai dari kualitas dan harga terhadap kedua jenis teknologi acuan cetak tersebut.

Hal yang dicapai ketika observasi adalah membandingkan dua acuan cetak dengan dibantu alat quality control (QC). Sebelum membandingkan kedua acuan cetak, dilakukan pencetakan langsung dengan dua acuan cetak tersebut, menggunakan mesin ofset. Berdasarkan hasil pengamatan ini dapat diberikan rekomendasi terhadap pemakain acuan cetak untuk cetak kemasan.

\section{HASIL DAN PEMBAHASAN}

A. Sistem pembuatan pelat image menggunakan film dan $\mathrm{CtCP}$ 
Sistem pembuatan pelat image dikarenakan masih menggunakan teknologi menggunakan film dan $\mathrm{CtCP}$ dilakukan yang sudah tertinggal. Dalam pembuatan berdasarkan observasi pada saat praktik acuan film yang harus dilakukan adalah: industri. Berikut pembahasannya:

1. Sistem yang digunakan oleh film 1. Pengolahan File cenderung lebih memakan waktu dibandingkan CtCP;

2. Biaya yang dikeluarkan cenderung lebih mahal untuk pembuatan acuan cetak menggunakan film dibandingkan $\mathrm{CtCP}$;

3. Hasil dari acuan cetak yang dicetak dalam bentuk kemasan, film lebih unggul dibandingkan $\mathrm{CtCP}$;

Pengolahan file yang dimaksud adalah dari penerimaan file yang berbentuk artwork, masuk kebagian pra cetak dan di-ripping setelah selesai lalu dipisahkan sesuai warna proses yaitu C, M, Y, dan K.

2. Pembuatan Film

Pembuatan film dilakukan setelah proses pengelolahan file terjadi, yang dimana nantinya operator memerintahkan image

4. Dari ketahanan film lebih kuat dibandingkan CtCP;

setter menggunakan komputer. Dan dari proses ini muncul output yaitu film separasi.

5. Bentuk raster (dot gain) kedua acuan berbeda pada saat sebelum dicetak;

3. Proses Imposisi Manual

Setelah pembuatan film separasi, film

6. Bentuk CtCP mengalami perubahan bentuk; tersebut harus diimposisi manual sesuai

7. Raster yang terbaca oleh film, tidak terbaca oleh CtCP.

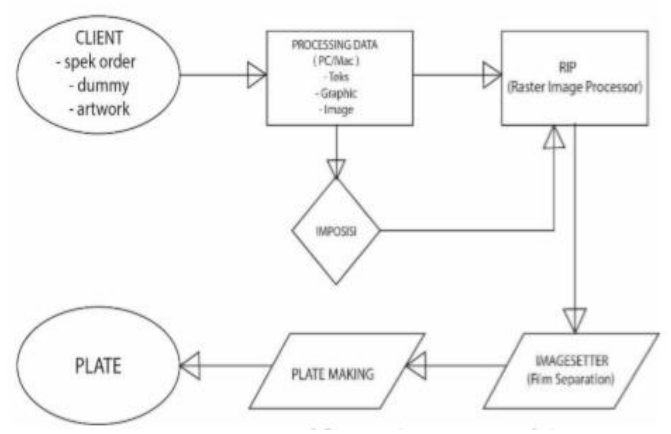

Gambar 1. Workflow CtF

\section{B. Sistem Pengepelatan Film}

Sistem pengepelatan dari film terbilang cukup lama dan mengeluarkan biaya yang lebih mahal dibandingkan $\mathrm{CtCP}$, dengan area cetak dan pelat yang digunakan. Film ditempelkan ke pelat dengan posisi terbaca, menggunakan solasi transparan dengan catatan tidak mengenai bagian image.

\section{Ekpose Film ke Pelat}

Setelah melalui imposisi manual pelat harus masuk kedalam mesin plate making, yang nantinya didalam mesin tersebut pelat yang sudah ditempel film disinari oleh sinar ultra violet selama 45 detik.

5. Pencucian Pelat Menggunakan Developer

Pencucian yang dimaksud adalah proses untuk merontokan emulsi pada pelat yang tidak 
masuk dalam area image yang sudah disinari di plate making. Cairan yang digunakan adalah developer dan air, dengan perbandingan 9:1. Setelah masuk kedalam cairan developer pelat kemudian dicuci kembali menggunakan air untuk membersihkan area permukaan pelat, lalu dikeringkan

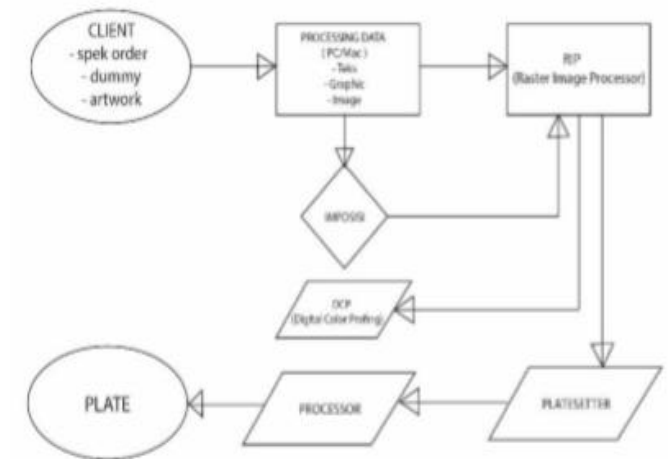

Gambar 2. Workflow CtCP

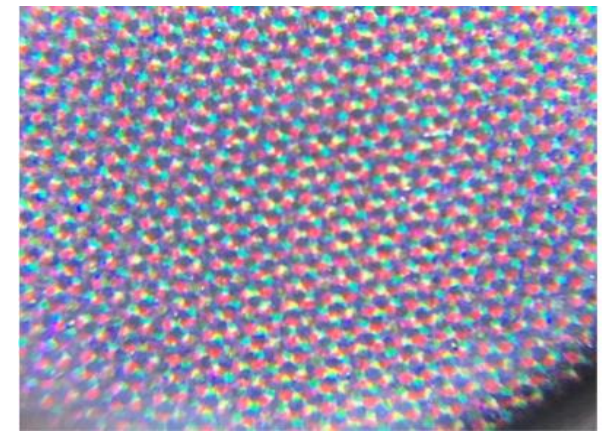

(a)

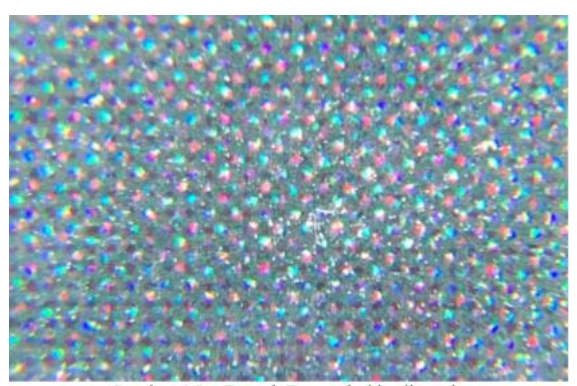

(b)

Gambar 3. Bentuk Raster dari hasil cetakan menggunakan lup

(a) pelat film dan (b) $\mathrm{CtCP}$
Sistem pengepelatan CtCP lebih

cepat dan murah dikarenakan sistem yang dilakukan langsung dan menghilangkan suatu proses yang sebelumnya ada di CtF, tentu teknologi yang digunakan lebih modern. Proses $\mathrm{CtCP}$ adalah sebagai berikut:

1. Pengolahan File

Sama seperti CtF hanya saja ada perbedaan dalam mengimposisi, jika film melakukan imposisi secara manual tetapi tidak dengan $\mathrm{CtCP}$ yang diimposisi langsung dalam komputer menggunakan software pembatu seperti arcitex atau preps lalu dipisahkan sesuai warna proses yaitu C,M,Y, dan K.

\section{Platesetter dan Developer}

Setelah dipisahkan sesuai dengan warna proses, operator dapat langsung memerintahkan pemindahan image ke pelat melalui komputer yang terhubung ke mesin platesetter dan developer. Hasil akhir ini nantinya langsung berupa pelat siap pakai.

Berikut perbandingan biaya untuk keduanya. Pembuatan film lebih mahal dikarenakan, membutuhkan alat atau bahan yang lebih banyak dan dari harga film itu sendiri adalah per sentimeter, dan untuk saat ini harga film per gulungan seharga 6 juta rupiah, dan juga membutuhkan pelat 
konvensional yang berkirsar harga 15 ribu sampai 20 ribu. Berbeda jauh dengan film, CtCP memiliki harga dipasaran 25 ribu hingga 30 ribu dan sudah berbentuk pelat siap pakai.

Perbandingan keduanya dari sisi dot again yaitu kedua acuan cetak memiliki perbedaan dengan kualitas cetak. Terbukti dari perubahan bentuk raster yang tadinya berbentuk seperti kotak untuk CtCP dan tidak terbacanya raster dibawah 5\% dan mengakibatkan image yang ada jadi tidak ada dalam pelat maupun cetakan tetapi hal ini tidak terjadi kepada acuan cetak film.

Untuk perbandingan konsisitensi warna, warna yang dihasilkan oleh film lebih baik dikarenakan bentuk raster (dot gain) yang rapih membuat warna tetap konsisten. Sedangkan CtCP memiliki warna yang cenderung gelap pada permukaan yang masih memiliki image dikarenakan raster yang tidak matang.

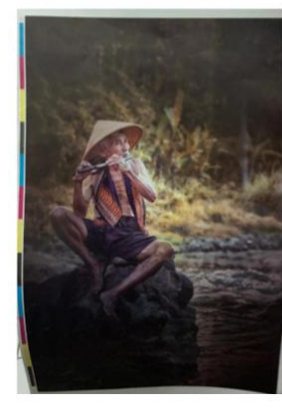

(a)

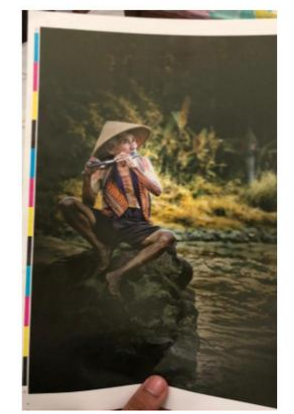

(b)
Gambar 4. Cetakan hasil (a)Pelat film dan (b)CtCP
Dalam mencetak dibutuhkan efisiensi, dalam membandingkan kedua acuan cetak ini, dilakukan uji coba. Uji coba yang dilakukan adalah mencetak menggunakan kedua acuan cetak tersebut di mesin ofset Heidelberg. Dalam proses tersebut didapatkan penentuan mana acuan yang lebih efisien. Pada saat make ready film cenderung lebih cepat menemukan warna dan tidak lama melakukan cetak coba untuk mencapai good copy. Sedangkan CtCP berbalik dengan film, lebih sulit dalam mencari warna sesuai dummy dikarenakan pada acuannya terdapat image yang sudah mulai tidak terlihat.

Rekomendasi yang diberikan adalah ketika ingin mencetak kemasan lebih baik memperhatikan dari aspek yang sangat menunjang cetak kemasan itu sendiri. Terutama cetak kemasan itu sendiri disebut sebagai cetakan istimewa (High Quality Printing). Dalam menunjang kebutuhan yang diharuskan dalam mencetak kemasan sebaiknya menggunakan film walaupun terbilang relatif mahal tapi cetakan yang dihasilkan baik dan kuat dalam ketahanan.

\section{KESIMPULAN}

Dari semua pengamatan yang dianalisa terdapat sebuah kesimpulan, perbedaan yang terdapat pada film dan $\mathrm{CtCP}$ disebabkan oleh proses penyinaran yang berbeda. Dimana film melalui dua kali proses 
penyinaran, dimulai dari pembuatan film menggunakan laser, dan disinarkan kembali dalam proses mentransfer image pada film ke pelat menggunakan plate maker dan disinari oleh sinar uv. CtCP dalam proses penyinaran, menggunakan laser. Dimana proses penyinaran menggunakan laser tidak merata dan membuat pelat tidak mendapatkan hasil raster yang matang. Proses ini sangat berpengaruh dengan hasil pelat. Hasil yang dimaksud adalah kematangan atau kerapihan raster setelah proses penyinaran, tentu hal ini akan mempengaruhi hasil cetakan akan baik atau tidaknya. $\mathrm{CtF}$ melewati proses yang berulang ulang tetapi hasil yang muncul lebih baik dari $\mathrm{CtCP}$.

\section{REFERENSI}

Dameria, A. 2008. In Basic Printing Panduan Dasar Cetak untuk Desainer dan
Industri Grafika. Jakarta.

Majid, Abdul dan Nurjalih. 2018. Pasca Cetak 2. Jakarta: Politeknik Negeri Media Kreatif Jakarta.

Nursidhi, Agus. 2018. Cetak Datar/Ofset.

Sudiyamto. 2011. Buku Ajar Teori Dasar Cetak Ofset. Jakarta: Politeknik Negeri Media Kreatif.

Susanto, A. S. 2013. Indonesian Printing Industry Trends, Current Technology, and Future Development. Journal of Printing Science and Technology, 50(1),hal.046-056.

Wasono, Antonius Bowo. 2008. Teknik Grafika dan Industri Grafika Jilid 1. Direktorat Pembinaan Sekolah Menengah Kejuruan.

Wasono, Antonius Bowo. 2008. Teknik Grafika dan Industri Grafika Jilid 2. Direktorat Pembinaan Sekolah Menengah Kejuruan. 